\title{
Prejudice, homophobia and the Christian faith community
}

\author{
Y Dreyer \\ (University of Pretoria)
}

\begin{abstract}
\end{abstract}
\section{Prejudice, homophobia and the Christian faith community}

The aim of the article is to illustrate that prejudice differs fundamentally from legitimate presuppositions that come into play when people interpret the Bible or reflect theologically on contemporary issues such as homosexuality. It is argued that prejudice leads to the theologically untenable phenomenon of homophobia. Though the rejection of prejudicial attitudes does not mean that "anything goes", it is a theological necessity to expose harmful attitudes and behaviours regarding sexuality. To this end the article investigates the labels "homosexual", "gay" and "queer" that, on the one hand, express and perpetuate homophobia and on the other hand represent a search for authentic identity on the part of sexual minorities. The article reflects on the effect of underlying social identity theories on homophobia. Such theories include nominialism with its focus on "sameness" and essentialism that focuses on "difference", as well as primordialism with its emphasis on the immutability of social identity formation and constructionism that highlights change.

\section{PREJUDICE, NOT PRESUPPOSITION}

When Christian faith communities grapple with the complex phenomenon of homosexuality, the prevalent prejudice and homophobia in church and society should be acknowledged openly and honestly if their harmful effects are to be eradicated. First of all it is necessary to distinguish between the concepts "presupposition" and "prejudice". It is unavoidable to approach any given issue with one's own set of presuppositions. Human beings are not able to be "objective", but bring their own histories, experiences and feelings to all their interactions with others and the world. Presuppositions as such are not negative. They simply form part of who we are. This value-neutral position of presupposition can, however, be used to obscure the decidedly negative and harmful attitudes and feelings that constitute prejudice. Therefore it is necessary to distinguish between "presupposition" as a sine qua non, and its negative, even evil counterpart "prejudice", which is harmful to others. By doing 
harm to others, one inevitably ends up harming oneself. Especially with regard to sexual minorities it is imperative to expose attitudes and feelings which negate, demean and harm others as prejudice.

Both from an ethical and a theological point of view prejudice is inexcusable. Theologically speaking, harmful attitudes, feelings and behaviour constitute transgression of the second half of the Great Commandment. They therefore cannot be acceptable in any form. Harmful social interaction cannot be condoned by the church.

When confronted with life issues and ethical questions, the faith community searches for guidelines in the Bible. The acknowledgement of one's presuppositions forms an integral part of Biblical interpretation. It is imperative that the faith community, in its dialogue with the Bible on the issues of sexuality and homosexuality, should search honestly for prejudicial attitudes which might be contaminating its presuppositions. The way in which the Bible has been interpreted in the past and is still being interpreted by some, has been harmful to sexual minorities. Biblical texts have been used against people without admitting to the underlying prejudicial presuppositions on which the exegesis was built.

Both the authors and interpreters of Biblical texts were bound to contexts which were temporally, psychologically, culturally and socially determined. They existed in a specific time, were prone to specific attitudes and expressed themselves by means of specific cultural codes. They lived their lives within specific relationships. All of this contributed to their perceptions of reality, their experiences, communications and interactions. Any investigation whether scientific in nature or not - begins with the presuppositions of the person who is asking the questions. This is the insight of Rudolf Bultmann (1957:409-417) who states that presuppositionless understanding is not possible. The search for understanding is informed and guided by the presuppositions of the interpreters and their shared social values within a particular paradigmatic circle. Presuppositions precede understanding.

Non-positivist investigation acknowledges that presuppositions exist, and then proceeds to identify and test them. This is also true for the exegesis of biblical texts and of creedal and other theological assertions. All investigations build on sociological, anthropological and psychological presuppositions. Investigations are about gathe- 
ring and interpreting data. Three aspects are of importance in the process of investigation: the interpreter, the matter to be interpreted, and the way in which the interpretation is done.

According to the insights of the sociology of knowledge, all knowledge is socially conditioned and perspectival. Sociologists of religion, Peter Berger \& Thomas Luckmann (1967:3) formulate it as follows: "[I]n sofar as all human knowledge is developed, transmitted and maintained in social institutions, the sociology of knowledge must seek to understand the processes by which this is done in such a way that a taken-for-granted 'reality' congeals for the man in the street." The knowledge of the interpreter, the circumstances surrounding the matter that is investigated, and the methods used, are the products of social conditioning. This means that "objectivity" is indeed nothing but a frustrated ideal of positivism (see Mouton 1987:1-29).

Berger \& Luckmann (1967:4) refer to the Seinsgebundenheit ("being bound to or determined by one's existence") of human knowledge. According to the sociology of knowledge, reality itself is a social construct, a product of socially conditioned observation. According to this view, authors of texts - present or past - give creative expression to reality. These expressions are produced within the constraints of history and are shaped by the personal and social experiences of the authors, who share a framework of credibility with their audiences. No communication or social interaction can take place outside of such shared social and cultural frameworks. Beliefs expressed in language, are credible within a specific frame of reference. Within this framework concepts are shared and views that contribute to meaning making, can be appropriated. Communication happens within a framework of shared concepts and a common context. In this way truth claims gain credibility and convictions acquire power. Also within this framework unacceptable points of view and harmful interactions will be exposed.

Non-positivist investigation requires investigators to acknowledge their personal and social points of departure, the presuppositions with which they approach their research. Secondly investigators should take into account how their research findings may influence and be influeced by their personal interests, presuppositions and preunderstandings. Probably the most difficult task is to scrutinise whether prejudice has guided their research goals 
and findings, whether consciously or unconsciously. A lack of awareness of one's own prejudice and of the distinction between presuppositions and prejudice will result in a specific way of using Scripture.

Fundamentalist interpretation will use the Bible to support certain dogmatic views regarded as "objective truth", regardless of the harm done to people's lives. According to such a positivist approach, "truth" is regarded as a true version or "imitation" of reality. "The truth" and reality are therefore in full accordance. This "objective reality" is passively received by human beings who play no part in searching for or creating truth. They are given it. The ostensible advantage is that truth is not relative, but a fixed norm from the outside. The disadvantage is that human beings remain passive. This view negates the human endeavour to investigate, grapple with and articulate "truth". It denies the social conditioning of knowledge.

The opposite position is that human beings produce truth. When actively involved in interactions such as communication and behaviour, they become aware that their views and attitudes can hurt or harm others. Presuppositions can no longer be used to legitimate and enforce so-called "objective truths" irrespective of the consequences to others. Such a relational view of truth, as opposed to an objective view of truth, necessitates a pastoral attitude towards people. Over against "objective truth" this idea of truth can be described as a "subjective view of truth". Truth is not to be found in things (objective), but in the actions of people (subjective).

In sociological terms this is the difference between "primordialism" and "constructionism". The concept "primordiallism" is associated with Edward Shils (1957) and Clifford Geertz (1963), and "constructionism" is the notion of Frederik Barth (1969). Primordialism is the idea that groups have intense, passionate, emotional bonds which cannot be explained. These bonds are based on family, territory, language, custom and religion. They are deeprooted, fixed and involuntary, so much so that they are thought to be "natural affections". The bonds are so compelling that they are regarded as "sacred" or "primordial". In this view social identity is not a matter of choice (least of all rational choice), but of tradition and emotions evoked by a common ancestry. 
Constructionism, or the self-ascriptive approach to social identity, is an alternative to primordialism. According to this view, social identity is not inherent, fixed and natural, but freely chosen and continually constructed by members of the group. The act of social boundary marking is more important than the "cultural stuff" enclosed by those boundaries. How and why peer groups generate and maintain group boundaries, are of interest. Difference in social identity exists in opposition, for example heterosexual versus homosexual. Difference can also be seen in social organization. Boundaries between groups are more of a process than a barrier. Difference is the visible and variable manifestation, but not the cause of boundaries or identities. Difference does not constitute, but signals social identity and boundaries. Maintaining identity is not about holding on to some specific or fixed content. Rather social identity is seen as fluid: it is self-ascriptive, continuously renewed and renegotiated through social practice.

According to constructionists, groups define themselves in two ways: firstly in relation to like-minded, like-practicing peers, a "we" aggregative self-definition, and secondly, in relation to others, a "we-they" oppositional self-definition. A further development based on constructionism, is instrumentalism, according to which a group's self-construction is seen as rational, self-interested and deliberately mobilised in order to promote its agenda of survival. Sociological theorists (see Esler 2003:46-48) agree that people ascribe social identity to themselves (constructionism), but they disagree on whether it is irrational and ineffable (primordialist) or rational and self-interested (instrumentalist). Most probably circumstances will dictate which mode is in operation at any given time. Since social identity affiliation is strong, individuals and groups have the power to modify identity for particular social, political, or religious reasons. The constructionist approach to social identity is generally the more prevalent one among social scientists. However, members of a particular social group - especially if threatened - are more likely to adopt a primordialist rather than a constructionist or instrumentalist view of identity.

Constructionist views can be found in philosophy (idealism, existentialism) as well as in some forms of liberal theology. In constructionist thought "truth" is not seen as an object to be studied, but as something which comes to light gradually after much searching. Truth is not about what can be observed by the senses. It 
is not about information which can be grasped rationally. The idea that nature cannot simply be observed "as it is", is gaining ground. It is increasingly acknowledged that human views and beliefs play a determinative part in observation. Observers do not merely mirror reality. Their presuppositions are active participants when they describe "reality".

These insights have changed the view of truth. Truth is no longer seen as an objective reality independent of human beings, nor merely as the subjective observation of human beings. It is also not a combination of the two. Rather, truth is to be found within relationship - in the engagement of human beings with something outside of themselves (see the report on view of Scripture and the authority of Scripture of the former Gereformeerde Kerken Nederland, God met ons 1981:6, 12 ). The search for truth presupposes interaction between the subject (the interpreter) and the object (the interpreted) - both functioning within their own social condition and locality.

Social condition refers to all the factors that influence a individual or a group: socialisation, experiences, perceptions, the framework of their rationality and their view of reality. It includes factors such as gender, sexual orientation, age, ethnic background, class, status, roles, vocation, nationality, social groups, political and religious affiliations, language and culture. All of these factors contribute to why people's views and the meanings they attribute to things or events, differ. All of this should be taken into account when Christian faith communities reflect on sexuality and homosexuality. This article attempts this when it aims to demonstrate:

- how prejudice (not legitimate presuppositions) leads to the theologically untenable phenomenon of homophobia;

- that rejecting prejudicial attitudes does not mean condoning everything with regard to sexuality; a relational view of truth can assist in finding a viewpoint beyond either "if it feels right" or "anything goes" (Loader 2005:vii);

- the role of labelling, by investigating the labels "homosexual", "gay" and "queer";

- social scientific insights regarding the relationship between personality types and views on gender; 
- the effect of underlying social identity theories on homophobia, for example nominalism with its focus on "sameness" and essentialism with its focus on difference (cf Holmén 2001:158159); primordialism with its emphasis on the immutability of social identity formation, and constructionism which highlights change;

- the influence of social identity theories on gay-friendly or gayunfriendly psychotherapy.

Labelling and its relation to homophobia will now be examined.

\section{WHAT'S IN A NAME?}

The transformation in the late 1960s of homosexual societies from being "in the closet" to public gay rights organisations was the beginning of the public discourse on homosexuality. The question is whether sexual attraction, sexual love and/or activities constitute a sexual identity (Schneider 2000:207-208). After the introduction of the term "homosexual" by a Swiss doctor, it was first seen as a pathologising medical term which reflects the modernist prejudice that heterosexuality is normative, natural and/or healthy. Therefore, what differs from it must be wrong, deviant and/or sick. Postmodern gay philosopher Michel Foucault's ([1976] 1978) work, History of sexuality, spearheaded "queer theory" by providing language with which to articulate criticism against heterosexual dominance (see Sedgwick 1985, 1990; Halperin 1990, 1995, 1998; Butler 1990, 1993). Over against the modernist idea of a fixed sexual identity, queer theory sees identity as a "function of historical and social processes" (Schneider 2000:206). Identity is as much a cultural production as is power, and as such it should be viewed with suspicion and not simply taken for granted.

The term "queer" indicating men who were sexually attracted to men, was coined in opposition to the term "homosexual". Since "queer" was also used in a derogatory way, however, a more preferred term in the broader culture was "gay". The term "gay" which previously denoted "women of dubious morals" (Jagose 1996:72), was taken over to refer to homosexual men and carried with it the connotation of effeminacy. In the 1960s and 1970s "gay" was seen to express a "more positive self-image and identity" (Schneider 2000:207) than the other prevalent terms. 
Sympathetic scholars of religion informed by queer theory, have diverged in two directions. Some focus on the problems of injustice and the marginalisation of gay persons in religious communities and in the broader community. Others prefer to take on "the whole paradigmatic system of meaning that produces heterosexuality and homosexuality in the first place, and they view biblical texts and traditions as cultural means of production for that system" (Schneider 2000:208).

Queer theory goes beyond the narrower meanings attached to terms such as gay, lesbian or homosexual. Rather than the binary opposition of homosexual and heterosexual, queer theory includes all possible categories of sexual identification, such as for example "bisexual", "transvestite" and "transgendered". Some theologians regard homosexuality as a natural, albeit small part of human sexuality. Queer theory does not accept this view of "natural" homosexuality on the grounds that it is too essentialist with regard to nature and disregards the powerful forces operating in the cultural construction of sexual identity. The focus on identity as a socially constructed system of meaning does not apply only to "queer people”, but is equally relevant to all identity formations. According to Michael Warner (1999; cf Schneider 2000:210) cultural systems have been constructed to render sex invisible because it is perceived as something shameful. Schneider (2000:211) criticises queer theory for not adequately taking into account the difference made by other shaping factors such as gender, race, class and ethnicity. Queer theory suggests that "normative heterosexuality is a social construction that needs homosexuality in order to retain its normdefining status” (Schneider 2000:211).

An example of how a queer theorist might approach biblical texts is given by Schneider (2000:208):

A queer theorist engaging the relevant biblical texts on apparent homosexual prohibitions may well accept the prohibitions as such, but will be more interested in their perceived necessity and the dynamics of power that they reveal than in any culturally transcendent moral claims that they can possibly make. Indeed, queer theory's radical historicism rejects any claims to deontological authority anywhere except as fabrication and deployment of power. 
With this approach, queer theory joins the theological debate "about the sources and authority of traditions that define social norms and human identities in terms of sin, redemption, good and evil, particularly as these categories are expressed through gender and race" (Schneider 2000:209). In this process many different categories of people have been marginalized. “Queer” people simply join their ranks. "Norms cannot abide difference" (Schneider 2000:210). Schneider (2000:212) remarks: "What queer theory principally provides is an intellectual framework for treating sexuality as a meaningful site of difference that could illuminate texts and traditions in helpful if sometimes unsettling ways.”

\section{PREJUDICE AS A DESTRUCTIVE FORCE}

The struggle of certain groups of people against negative labels and their quest for language with which to articulate an authentic sexual identity for themselves, in itself demonstrates that something is terribly wrong. As part of a sexual minority, they have been typified as "different" in a dehumanising way. They have been stripped of the privacy with regard to sexuality, which the heterosexual majority takes for granted. A heterosexual person's sexuality is simply none of anybody's business. The sexuality of people belonging to sexual minority groups, however, is brought into the public domain: they are labelled, discriminated against in various ways, demeaned and physically assaulted on account of their sexual identity. All of this points to the underlying prejudicial attitudes and behaviours of the majority. This form of disrespect and prejudice has been termed "homophobia". Homophobia is the result of harmful prejudice and is also instrumental in perpetuating prejudice. This, in turn, leads to harmful and destructive behaviour. Therefore homophobia should be exposed and eradicated. A constructionist approach to sexuality may be useful in this regard.

The fact that homosexuality "exists as a practice everywhere, but different cultures understand it differently and only some designate it an illness or a deviation from a norm” (Young-Bruehl 2003:147), supports an anti-essentialist, cultural constructionist approach. In his ground-breaking study, The nature of prejudice, psychologist Gordon Allport (1958) describes how prejudice is socially constructed: the target is some group which is different, and that difference then becomes the defining characteristic of the group. In 1972 the Gay Liberation Movement set out to combat the 
prejudice termed "homophobia". The term refers to "a fear of homosexuality in others (and probably in oneself) and frequently implies verbal and physical aggression towards individuals (self-) identified as lesbian or gay" (Gough 2002:219). The target of this prejudice is "homosexual" individuals or people belonging to other sexual minorities. The difference is in their sexual practices, and this difference is used to define them as a group.

Social institutions play their part in perpetuating prejudice towards and discrimination against sexual minorities. Maledominated institutions such as the law, the military, religious groups and medicine (Gough 2002:219; see Herek 1989:948-955, 1998; Blumenfeld 1992) have been notorious for this. At first the sexual practices or minorities were labelled "pathological" in relation to the sexual practices of the heterosexual majority. Gay individuals were treated for their "pathology" with for instance aversion therapy shock treatments. Later, in 1979, homosexuality was depathologized by the American Psychiatric Association and removed as a category from the DSM. However, this did not have the effect of eradicating the oppression of sexual minorities. Gough (2002:220; cf Segal 1990) points out: "Despite the declassification of homosexuality as a mental illness and the growing visibility and confidence of gay communities since the 1970s, widespread public acceptance has proved elusive; indeed, homophobia has burgeoned over the past twenty years."

If a group such as, for instance, gay people, does not "live up to" the definitions constructed of them, but rather individuals show themselves to be successful, strong, capable of long-term relationships, people who decline to be identified by others, but who identify themselves, the prejudice intensifies and new mechanisms are sought to "keep them in their place" - a place designed for them by prejudice in the first place. The backlash in the United States, for example, takes the form of new levels of violence against gays and official policies which keep them out of or closeted in institutions such as the military.

On the other hand there has been a shift towards greater tolerance of sexual minorities as dominant heterosexuality is undergoing change. Sex no longer has the sole purpose of procreation, life-long monogamy is no longer the ideal, marriage as an institution is declining and alternatives to the nuclear family model of the 
middle of the $20^{\text {th }}$ century are developing (Young-Bruehl 2003:150151). In the past heterosexuality was seen as serving family and family life, whereas homosexuality served only the pursuit of individual pleasure. As these differences have diminished, gays are not longer so totally “other” (see Dreyer 2005:729-751)

The anti-essential postmodern approach to sexuality is based on a "constructionist" view of sexual identity. According to Müller \& Pienaar (2003:140), such an approach does not view "[o]ne relationship [as] a carbon copy of the next". This "realisation", according to them, "does away with so-called objective uncontextualised knowledge about wrong or right sexual conduct in relationships." Anti-essentialism opposes the idea that people "have a timeless, universal core which ultimately explains their actions" (Ward 1997:136). Sexual identity is a cultural rather than a natural or essential category. Glen Ward (1997:136) states that, because of essentialism's attempts to define people's “proper sexual place in terms of what is supposedly natural, it has become important to dispute the way in which society habitually calls upon an idea of 'nature' as the ultimate explanation of things which happen within culture." As far as sexuality is concerned, postmodern criticism levelled against modernity's a-historical, biologically and psychologically "essentialistic" views, has challenged the discussion to include the "thoroughly social, cultural and historical conceptualization and constitution of sexuality" (Stone 2000:235).

Contributions have come from different fields. Sociology and psychology have provided the insights that sexual behaviour is the result not only of biology, but also of a complex mixture of cultural symbols and role expectations in dialogue with intrapsychic scripting and internal dialogue (Stone 2000:235; cf Gagnon \& Simon 1973; Simon 1996). Anthropology has demonstrated that sexual practices and their meanings vary substantially across different cultures. This has brought the validity of general and generalising statements about sexuality into question. Biological and psychological determination have had to make way for views which take the impact and meanings of socio-cultural organisation and interpretation seriously (Stone 2000:235; see Herdt 1997; Caplan 1987; Vance 1989; 1991:875-884). Historical analysis has pointed out that, over time, differences will occur even within one culture. As social aspects such as kinship, gender relations, ideologies, demographic changes, mobility, occupations, class relations and 
ethnicity change, so sexuality takes on different forms and meanings (Peis \& Simmonds 1989; Weeks 1985, 1986, 1989; D’Emilio \& Freedman 1997; Seidman 1990, 1992; Giddens 1992). In theology, ecclesial institutions are challenged by critical theory to take the following into consideration:

- that the interconnectivity of sexuality, religion and marriage should be deconstructed (see Dreyer 2005: 2005:729-751);

- that male domination with regard to sexuality, religion and marriage should be opposed by the church; this opposition should manifest in the attitudes, behaviour and deeds of faith communities and church organi-sations;

- that the prejudice which creates and maintains homo-phobia should be exposed for what it is - an un-Christian attitude which is in opposition to the values advocated by the church.

From a psychoanalytical perspective Elisabeth Young-Bruehl (2003:149) describes the process of the creation of prejudice as follows: “... people who fear their own drives will characteristically try to locate those fearsome drives outside of themselves - and for this they need others. And a category, 'the other'”. Depth psychology was familiar with individuals' use of projection as a defence mechanism in response to anxiety or threat. Prejudice functions in a similar way, but is social rather than individual and "operates upon external objects rather than upon intrapsychic wishes and objects" (Young-Bruehl 2003:152). In other words prejudices can be seen as social mechanisms of defence. A plurality of motivations for prejudices exists. There are also many character types or personalities "for whom prejudices are life-organizing" (Young-Bruehl 2003:158)

Since the construction of prejudice serves these kinds of psychological needs and is not an accurate description of an existing phenomenon, Young-Bruehl (2003:157) views the categorisation of homosexual and heterosexual as artificial. For her a solution to the problem of homophobic prejudice would be to say about people: "all humans are sexual in one way or another, or in more than one way, or in one way now and another way later; all humans are sexually quite labile and make more than one sexual object choice." The group identity of "homosexual" and all the theorising done around it, tend to keep in place the artificial categorisation of heterosexual and homosexual, based on the original identification of what is different in order to construct prejudice against a group around that 
difference. A positive identity over against the negative one of prejudice is necessary in order to bring closeted and persecuted people to the point where they can live more freely and with human dignity.

A next step, according to Young-Bruehl (2003:157) would be for "homosexual" people to assert: "We are fighting to make ourselves unnecessary as instruments of other people's defensive needs; we are looking forward as we assert ourselves as a group to the time when we will not be forced to be one". In his work, The invention of heterosexuality, Jonathan Katz (1995) points to signs that normative heterosexuality is on the decline. More and more "heterosexual" people organise their lives, sexuality and family life in a way that differ from the usual definitions of heterosexuality. This is also an indication that the previously polarised categories of homosexual and heterosexual are moving closer together. Psychologists emphasise that the elemental human need for loving affection, care-taking and attachment does not exist only when tied to specific love objects of either the same or the opposite sex. It is just that: an elemental need of all people.

Prejudice as a destructive force in human society should be confronted wherever it manifests. How to go about this, is elaborated on by Young-Bruehl (2003:159) from a psychological perspective: "The task of combating homophobias has to be aimed ultimately, at the roots of the prejudices in characters and character pathologies, and thus aimed, too, at all the social conditions that promote those characters and pathologies". With the useful insights of psychology, religion, faith communities and theology can take their place as partners in this enterprise of promoting the well-being of all individuals, all groups and society as a whole. The task of religion and faith communities will then be one of honest introspection and healing action. Firstly, the roots of prejudice will have to be identified and the fears of peoples in Biblical cultures and presentday cultures examined. Then the social mechanisms used to assuage those fears and which have been harmful to others, should be exposed, and the part played in it by religion and churches, confessed. Only then can healing take place on both fronts: the perpetrators and the victims of the prejudice of homophobia can be liberated. 


\section{PURGING PRESUPPOSITION FROM PREJUDICE}

A presupposition central to this article is that Scripture provides a guide to human behaviour for those who believe. Behaviour is about relationships and interaction among people. Some people are homosexual in their orientation and behaviour. Others are homophobic in their attitudes and behaviour. Homophobia constitutes an irrational fear and disgust of homosexuality. This can lead to the internalisation of homophobia where people of sexual minorities take the negative attitudes of society into themselves, much to their own detriment. When gays experience homophobia in the faith community, it causes inner conflict between who they know themselves to be and the institutionalised norms of the church, supposedly based on the Bible. The Encyclopedia of Homosexuality (Johansson 1990:648-649; cf Ellison 1993:149) put it bluntly: "For homosexuals the Judeo-Christian tradition has meant nothing but ostracism and punishment, exile and death ..."

In a previous article (Dreyer 2004) I pointed out that opposing views based on two different sets of presuppositions are held in the Christian church. Both claim to be based on Scripture. Both interpret the relevant biblical texts within their cultural contexts, but they come to very different conclusions. From the perspective of "essentialistic" sociological theories both can be regarded as "biblicistic" (see Seitz 2000:177). The debate on homosexuality is the manifestation of a crisis in the Christian church. This article poses the question whether the difference in presuppositions which leads to different approaches to Scripture and very different theological viewpoints on homosexuality, may be caused by prejudice. If prejudice is the culprit, this cannot be acceptable to the faith community in light of the gospel. Prejudice in the church, which contributes to the marginalisation of sexual minorities, should be exposed. Both prejudice nor marginalisation are unacceptable to the faith community, since they are in opposition to the gospel message.

Since the beginning of the Christian faith community, the marginalised were welcomed and all were considered equal. Love was the norm which was expressed by caring for one another. This is described as follows by Helmut Koester (in Hazel 2000:16): "People are taken out of an isolation ... Christianity really established a 
realm of mutual social support for the members who joined the church. So, Christianity could adjust to different types of people”.

According to the sociologist of religion, Rodney Stark (in Hazel 2000:16), the aim of the Christian faith was to create a moral climate within culture, emphasising values such as mercy: "Be merciful as I am merciful” (Lk 6:36). Because of God's love for human beings, people cannot serve God if they do not love one another. This was a novel idea during the time of the New Testament. It was even more revolutionary to think that Christian love and charity should also be directed toward people outside of the family circle or ethnic group.

It is on account of this that homosexual people seek acceptance in Christian faith communities. Also in the earliest Jesus movement (e.g., Paul's controversy with the Judean movement under the leadership of Peter and James in Jerusalem), prejudice was camouflaged by so-called acceptable presuppositions regarding the use of Scripture. Paul (see Gl1:6-10) referred to this prejudice as a "so-called gospel" which is "no good tiding at all". Such prejudices became obstacles to the inclusion of marginalised people in the family of God (cf Hazel 2000:16).

Jesus brought hope to marginalised people who were regarded as unacceptable within Israelite culture - unacceptable to Israelite people and to Israel's God. The hope Jesus gave them was that they too could live in God's presence. There were no conditions. Access to God's presence was as possible for them as for people who were not marginalised. However, it should be emphasised that marginalised people were not included in the kingdom of God because of their condition, but rather in spite of it. Through their inclusion God's love was shown to be different and much greater than that of human beings who can only love conditionally and who exclude those they deem unworthy.

The gospel message of inclusivity emphasises God's grace. Human beings live from faith and grace alone. Therefore homosexual people should not be accepted by the church because they have been marginalised. They should be accepted because all who believe in Jesus Christ are welcome in the Christian faith community. There are no conditions. Prejudice should not get in the way of the church being church as it should be - following in the footsteps of Jesus. According to the gospel message all people are unconditionally reconciled with God, irrespective of their physical 
circumstances. This is true for homosexual and heterosexual persons (or any other categories of people). All people are equal before God. If the church chooses to exclude people from the faith community or from serving God, then the life of the church does not attest to the grace of God and the "truth of the gospel message". In Luke 17:18 Jesus exposes prejudice against an outsider. Izak du Plessis ([1995] 1996:560) comments as follows: It is an outsider who recognises Jesus as agent of God and thanks Him. Those who supposedly were believers and who should have thanked God, were only interested in their own healing. This outsider is used by Jesus to break down prejudice”.

\section{Consulted literature}

Allport, G W 1958. The nature of prejudice. Garden City, NY: Doubleday.

Barth, F (ed) 1969. Ethnic groups and boundaries. Boston, MAS: Little Brown.

Butler, J 1990. Gender trouble: Feminism and the subversion of identity. New York: Routledge.

-, 1993. Bodies that matter: On the disursive limits of "sex". New York: Routledge.

Berger, P L \& Luckmann, T 1967. The social construction of reality: A treatise in the sociology of knowledge. New York, NY: Doubleday.

Blumenfeld, W J 1992. Homophobia: How we all pay the price. Boston, MA: Beacon Press.

Bultmann, R 1957. Ist voraussetzungslose Exegese möglich? Theologische Zeitschrift, 409-417.

Caplan, P et al 1987. The cultural construction of sexuality. New York: Routledge.

D'Emilio, J \& Freedman, E W 1997. Intimate matters: A history of sexuality in America. $2^{\text {nd }}$ edition. Chicago, Ill: University of Chicago Press.

Dreyer, Y 2004. Homoseksualiteit: Kerk, tradisie en die Bybel - homofobie en sarkofobie en die evangelie HTS 60(1\&2), 175-205.

-, 2005. Sexuality and shifting paradigms - setting the scene. HTS 61(3), 729751.

Du Plessis, I [1995] 1996. Die Evangelie volgens Lukas, Deel II. Kaapstad: Lux Verbi. (Kommentaar op die Nuwe Testament: Struktuur - uitleg boodskap).

Ellison, M M 1993. Homosexuality and Protestantism, in: Swidler, A (ed), Homosexuality and world religions, 149-179. Valley Forge, PA: Trinity Press International. 
Esler, P F 2003. Conflict and identity in Romans: The social setting of Paul's letter. Minneapolis, MN: Fortress.

Foucault, M [1976]1978. The history of sexuality, Vol 1: An introduction, tr by R Hurley. New York: Random House.

Gagnon, J \& Simon, W 1973. Sexual conduct: The social sources of human sexuality. Chicago, Ill: Aldine Publishing.

Geertz, C. 1963. The integrative revolution: Primordial sentiments and civil politics in the New States, in Geertz, C. (ed.), Old societies and new states, 105-57. New York: The Free Press].

Giddens, A 1992. The transformation of intimacy: Sexuality, love and eroticism in modern societies. Stanford, CA: Stanford University Press].

God met ons: Over de aard van het Schriftgezag 1981. Speciaal kerkinformatie, Nummer 113, Gereformeerde Kerken (Nederland). Utrecht: Tijl-Libertas.

Gough, B 2002. “I’ve always tolerated it but ...”: Heterosexual masculinity and the discursive reproduction of homophobia, in: Coyle, A \& Kitzinger, C (eds), Lesbian and gay psychology. Oxford, UK/Malden, MA: BPS Blackwell.

Halperin, D M 1990. One hundred years of homosexuality and other essays on Greek love. New York: Routledge.

-, 1995. Saint Foucault: Towards a gay hagiography. New York: Oxford University Press.

-, 1998. Forgetting Foucault: Acts, identities, and the history of sexuality. Representations 63, 93-120.

Hazel, D 2000. Witness: Gay and lesbian clergy report from the front. Louisville, KY: Westminster John Knox.

Herdt, G 1997 (ed). Same sex, different cultures. Boulder: Westview Press.

Herek, G M 1986. On heterosexual masculinity. American Behavioral Scientist 29, 563-577.

-, 1989. Hate crimes against lesbians and gay men. American Psychologist 44:948-955.

-, 1998. Stigma and sexual orientation: Understanding prejudice against lesbians, gay men and bisexuals. Thousand Oaks, CA: Sage.

Holmén, T 2001. The Jewishness of Jesus in the "Third Quest', in Labahn, M. \& Schmidt, A. (eds.), Jesus, Mark and Q, 143-162. Sheffield: Sheffield Academic Press.

Jagose, A 1996. Queer theory: An introduction. New York: New York University Press. 
Johansson, W 1990. s v Judeo-Christian tradition, in: Dynes, W R (ed.), The Encyclopedia of Homosexuality, Volume 1, 648-649. New York: Garland Publishing.

Katz J N 1995. The invention of heterosexuality. New York: E P Dutton.

Loader, W 2005. Sexuality and the Jesus tradition. Grand Rapids, MI: Eerdmans.

Mouton, J 1987. Die positivisme, in: Snyman, J J \& Du Plessis P G W (reds), Wetenskapsbeelde in die geesteswetenskappe, 1-29. Pretoria: RGN (RGNStudies in Navorsingsmetodologie 3).

Müller, J C \& Pienaar, H E 2003. A social-constructionist, narrative understanding of the church's morality on sex. Verbum et Ecclesia 24(1), 137155.

Peis, K \& Simmonds, C (eds) 1989. Passion and power: Sexuality in history. Philadelphia, PA: Temple University Press.

Shils, E A 1957. Center and Periphery: Essays in Macrosociology. Selected Papers of Edward Shils, vol. 2, 111-26. Chicago: Chicago University Press.

Schneider, L C 2000. Queer theory, in: Adam, A K M (ed), Handbook of postmodern biblical interpretation. St Louis, MO:Chalice Press.

Sedgwick, E K 1985. Between men: English literature and male homosocial desire. New York: Columbia University Press.

-, 1990. Epistemology of the closet. Berkeley, CA: University of California Press.

Segal, L 1990. Slow motion: Changing masculinities, changing men. London: Virago.

Seidman, S 1990. Romantic longings. New York: Routledge.

-, 1992. Embattled eros: Sexual politics and ethics in contemporary America. New York: Routledge.

Seitz, C 2000. Sexuality and Scripture's plain sense: The Christian community and the law of God, in Balch, D L (ed), Homosexuality, science and the "plain sense" of Scripture, 177-196. Grand Rapids, MI: Eerdmans.

Simon, W 1996. Postmodern sexualities. New York: Routledge.

Stone, K 2000. Sexuality, in: Adam, A K M (ed), Handbook of postmodern biblical interpretation. St Louis, MO:Chalice Press.

Vance, C 1989. Social construction theory: Problems in history of sexuality, in Altman, D et al, Homosexuality, Which homosexuality? Amsterdam: Uitgeverij An Dekker.

-, 1991. Anthropology rediscovers sexuality: A theoretical comment. Social Science and Medicine 33(8), 875-884.

Ward, G 1997. Postmodernism. London: Hodder Headline. (Teach Yourself). 
Warner, M 1999. The trouble with normal: Sex, politics, and the ethics of queer life. New York: Free Press.

Weeks, J 1985. Sexuality and its discontents: Meanings, myths and modern sexualities. Londen: Routledge \& Kegan Paul.

-, 1986. Sexuality. London: Routledge.

-, 1989. Sex, politics and society: The regulation of sexuality since 1800. London: Longman.

Young-Bruehl, E 2003. Homophobias: A diagnostic and political manual, in: Moss, D (ed), Hating in the first person plural: Psychoanalytic essays on racism, homophobia, misogyny, and terror. New York: Other Press. 